Takae Kawamura MD, Katsuya Inada MD, Hiroshi Okada MD, Kazutoshi Okada MD, Reiji Wakusawa MD

\title{
Methylprednisolone inhibits increase of interleukin 8 and 6 during open heart surgery
}

It has been reported that interleukin 8 (IL-8) and interleukin $6(I L-6)$ are two of the chemical mediators causing myocardial injury. $t h$ is not clear whether treatment with corticosteroids in vitro in these patients can prevent the production of interleukin 8 and 6. This prospective study was conducted to investigate whether methylprednisolone (MP) pretreatment 30 $\mathrm{mg} \cdot \mathrm{kg}^{-1}$ before $\mathrm{CPB}$ and before declamping of aorta) influenced the production of $I L-8$ and 6 in the peripheral circulation in 27 patients undergoing elective coronary artery bypass surgery. The $I L-8$ and $I L-6$ concentrations were measured by ELISA kit. We also studied the effect of MP pretreatment on postoperative cardiac function. Serum concentration of $I L-8$ in non-MP-treated patients ( $37 \pm 44 \mathrm{pg} \cdot \mathrm{ml}^{-1}$ preoperatively) increased to $169 \pm 86 \mathrm{pg} \cdot \mathrm{ml}^{-1} 60 \mathrm{~min}$ afier declamping of the aorta $(P<0.001)$. The increase was greater than the increase from $22 \pm 8.9 \mathrm{pg} \cdot \mathrm{ml}^{-1}$ to $52 \pm 35 \mathrm{pg} \cdot \mathrm{ml}^{-1}$ in the MP-treated patients $(P<0.01)$. Serum $I L-6$ concentration in non-MP-treated patients increased from the preoperative value of $59 \pm 30 \mathrm{pg} \cdot \mathrm{ml}^{-1}$ to $436 \pm 143 \mathrm{pg} \cdot \mathrm{ml}^{-1} 60 \mathrm{~min}$ after declamping of the aorta $(P<0.001)$. The increase was greater than the increase from $36 \pm 15 \mathrm{pg} \cdot \mathrm{ml}^{-1}$ to $135 \pm 85 \mathrm{pg} \cdot \mathrm{ml}^{-1}$ in the MP-treated patients $(P<0.01)$. Furthermore, postoperative cardiac index in MP-treated patients $3.6 \pm 1.1$ $\left.L \cdot \min ^{-1} \cdot \mathrm{m}^{-2}\right)$ was higher than $2.3 \pm 0.8 \mathrm{~L} \cdot \mathrm{min}^{-1} \cdot \mathrm{m}^{-2}$ of non $M P$-treated patients $(P<0.05)$. The levels of $I L-8$ max during surgery correlated negatively with postoperative cardiac index $(\gamma=-0.67)$. These results suggest that methylprednisolone suppresses production of $I L-8$ and 6 .

\section{Key words}

HEART: reperfusion injury;

HORMONES: cytokines, interleukins, methylprednisolone; ANAESTHESIA: cardiac, cardiopulmonary bypass.

\footnotetext{
From the Department of Anesthesiology, Iwate Medical

University, 19-1, Uchimaru, Morioka, Iwate, 020 Japan. Address correspondence to: Dr. Takae Kawamura. Accepted for publication 20th May, 1995.
}

On a rapporté que linterleukine $8(I L-8)$ et que l'interleukine 6 (IL-6) étaient deux des médiateurs chimiques de la lésion cardiaque. Toutefois, on ne sait pas encore si le traitement aux corticostéroïdes in vivo prévient la production des interleukines 8 et 6 . Cette étude prospective vise à déterminer si le prétraitement à la méthylprednisolone (MP) $\left(30 \mathrm{mg} \cdot \mathrm{kg}^{-1}\right.$ avant le CEC et avant le déclampage de l'aorte) influence la concentration de l'IL-8 de I'IL-6 du sang veinewx périphérique de 27 patients soumis à une chirurgie réglée de revascularisation myocardique. Les concentrations de l'IL-8 de l'IL-6 sont mesurée avec une trousse Elisa. Nous étudions aussi les répercussions du traitement à la MP sur la fonction cardiaque postopératoire. La concentration sérique de l'IL-8 des patients non traités (37 $\pm 44 \mathrm{pg} \cdot \mathrm{ml}^{-1}$ en préopératoire) augmente à 169 $\pm 86 \mathrm{pg} \cdot \mathrm{ml}^{-1} 60$ minutes après le déclampage de l'aorte $(P$ $<0,001)$. Cette augmentation est plus importante que l'augmentation de $22 \pm 8,9 \mathrm{pg} \cdot \mathrm{ml}^{-1}$ à $52 \pm 35 \mathrm{pg} \cdot \mathrm{ml}^{-1}$ notée chez les patients traité à la MP (P<0,01). La concentration sérique de l'LL-6 chez les patients non traités à la MP augmente de la valeur préopératoire de $59 \pm 30 \mathrm{pg} \cdot \mathrm{ml}^{-1}$ à $436 \pm 143$ $\mathrm{pg} \cdot \mathrm{ml}^{-1} 60 \mathrm{~min}$ après le déclampage de l'aorte $(P<0,001)$. Cette augmentation est plus importante que celle de $36 \pm 15$ $\mathrm{pg} \cdot \mathrm{ml}^{-1} \grave{a} 135 \pm 85 \mathrm{pg} \cdot \mathrm{ml}^{-1}$ survenue chez les patients traités à la $M P(P<0,01)$. De plus, lindex cardiaque postopératoire des patients traités à la MP $\left(3.6 \pm 1,1 \mathrm{~L} \cdot \mathrm{min}^{-1} \cdot \mathrm{m}^{-2}\right)$ est plus élevé que celui des patients non traités 2,3 $\pm 0,8$ $L \cdot \min ^{-1} \cdot m^{-2}(P<0,05)$. Les niveaux maximaux de l'tL8 sont en corrélation négative avec l'index cardiaque pastopératoire $(\gamma=0,67)$. Ces résultats suggèrent que la méthylprednisolone supprime la production de l'IL-8 et de l'IL-6.

There are many reports that, in reperfusion models, infarct size after myocardial ischaemia may be decreased by inhibiting infiltration of neutrophils into ischaemic myocardium, ${ }^{1-3}$ and attention has been focused on the possible role of neutrophils in reperfusion injury. The mechanism by which neutrophils cause myocardial ischaemia include the presence of free oxygen radicals, products of arachidonic acid metabolized by the lipooxygenase 
pathway, or neutrophil lysosomal enzymes including granulocyte elastase (GEL). These substances are induced after neutrophils are activated, suggesting that postischaemic reperfusion injury may be relieved if neutrophil activation were inhibited. Previously, we measured inflammatory cytokines such as IL-8 and IL-6 which are potent activators of neutrophils, during open heart surgery. From $60 \mathrm{~min}$ after reperfusion (declamping of aorta), plasma concentrations increased from levels seen before surgery and at $60 \mathrm{~min}$ after aortic occlusion, and these increases correlated with GEL and CK-MB, ${ }^{4}$ indicating that neutrophils, activated by the increased production of IL-8 and IL-6, were cytotoxic. In the present study, methylprednisolone, which has been shown to inhibit cytokines in vitro and in vivo, ${ }^{5-8}$ was given to patients undergoing open heart surgery, and its inhibitory effect on the increased production of IL- 8 and IL- 6 during open heart surgery was investigated. In addition, the effects of MP on the postoperative cardiac function were also observed.

\section{Methods}

With insituational approval and informed consent, this randomized study was performed in 27 patients undergoing elective coronary artery bypass surgery: Group I, 11 patients underwent standard CPB; Group II, 16 patients received $30 \mathrm{mg} \cdot \mathrm{kg}^{-1} \mathrm{MP}$ (Solumedrol ${ }^{\circledR}$, Upjohn Ltd.) $i v$ before CPB and before declamping of the aorta. Preanaesthetic medication included diazepam $(0.2$ $\left.\mathrm{mg} \cdot \mathrm{kg}^{-1}\right)$, hydroxyzine $\left(1 \mathrm{mg} \cdot \mathrm{kg}^{-1}\right)$, meperidine (1 $\left.\mathrm{mg} \cdot \mathrm{kg}^{-1}\right)$ and atropine $\left(0.01 \mathrm{mg} \cdot \mathrm{kg}^{-1}\right)$. Anaesthesia was induced with fentanyl $\left(30 \mu \mathrm{g} \cdot \mathrm{kg}^{-1}\right)$, and tracheal intubation was facilitated with vecuronium $\left(0.15 \mathrm{mg} \cdot \mathrm{kg}^{-1}\right)$. Anaesthesia was maintained using oxygen, and high-dose fentanyl (total $100 \mu \mathrm{g} \cdot \mathrm{kg}^{-1}$ ). Ventilation was controlled to maintain $\mathrm{PaCO}_{2}$ at approximately $40 \mathrm{mmHg}$.

The perfusion apparatus included a hollow fibre membrane oxygenator (Terumo, Capiox) and nonpalsatile roller pump (Pemco Inc.). A mixture of $20 \%$ mannitol, $7 \%$ sodium bicarbonate, electrolyte solution, and CPDadded preserved blood was used for priming, and then perfused at a flow of $2.4 \mathrm{~L} \cdot \mathrm{m}^{-2} \cdot \mathrm{min}^{-1}$. Haematocrit concentrations were maintained at $20 \%$ or more throughout CPB. Crystaloid and blood cardioplegia was used for cardiac preservation.

The ECG, EEG, and oesophageal and rectal temperatures were monitored continuously. Arterial blood oxygen saturation was monitored continuously with a pulseoximeter (Datex, Satlite), and end-tidal carbon dioxide concentrations with capnography (Datex, Capnomac). A pulmonary artery catheter was inserted into the internal carotid vein and a catheter was placed in the radial artery to measure arterial pressure directly, and from which
TABLE I Clinical characteristics

\begin{tabular}{lcc}
\hline Group & Group I & Group II \\
\hline Patients & $n=11$ & $n=16$ \\
Age (yr) & $58 \pm 13$ & $58 \pm 14$ \\
BW (kg) & $52 \pm 11$ & $52 \pm 9.7$ \\
EF (\%) & $58.5 \pm 10.9$ & $59.7 \pm 13$ \\
CPB (min) & $181 \pm 41$ & $148 \pm 50$ \\
Ao clamp (min) & $87 \pm 31$ & $97 \pm 34$ \\
Cardioplegia (m) & $1993 \pm 560$ & $2047 \pm 659$ \\
& mean \pm SD & mean \pm SD \\
\hline
\end{tabular}

Values are mean \pm SD BW: body weight; EF: ejection fraction; CPB: cardiopulmonary bypass; Ao.clamp:aortic clamp time.

blood samples were drawn. Six blood samples were drawn after induction of anaesthesia, at the following times: before surgery, immediately before starting CPB, $60 \mathrm{~min}$ after aortic occlusion, and 60,120 and $180 \mathrm{~min}$ after declamping of the aorta. In each sample, IL-8, Il-6, GEL, CK and CK-MB concentrations were measured. The IL- 8 and IL- 6 were measured by ELISA kits (IL-8: R\&D systems Minneapolis, MN, USA, ${ }^{9}$ IL-6: Toray Fujibionics Inc, Tokyo, Japan), ${ }^{10}$ and GEL by enzyme linked immunosorbent assay as GEL- $\alpha_{1}$-PI complex. For statistical analyses, Scheffe's $F$ test was used for multiple comparison, and Student's $t$ test for betweengroup comparison. Significant difference was defined as $P<0.05$. Data were presented as mean \pm standard deviation (mean $\pm \mathrm{SD}$ ).

\section{Results}

Patients from the two groups did not differ in terms of age, body weight, ejection fraction, duration of $\mathrm{CPB}$, aortic clamping time and cardioplegic solution (Table I).

The serum concentration of IL-8 increased at 60,120 , $180 \mathrm{~min}$ after reperfusion (declamping of aorta) compared with the value before surgery in both groups $(P<0.01)$. The IL-8 concentration in Group II was less $(P<0.01)$ than that in Group I at each time point after reperfusion (Figure 1). The serum concentration of IL-6 increased $60 \mathrm{~min}$ after reperfusion and was maintained at a high concentration until $180 \mathrm{~min}$ after reperfusion compared with the value of before surgery in both groups $(P<$ $0.01)$. The IL-6 concentration in Group II was less ( $P$ $<0.01$ ) than that in group I at each time point after reperfusion (Figure 2). Plasma GEL and serum CK concentrations increased progressively at $60,120,180 \mathrm{~min}$ after reperfusion compared with the values before surgery $(P<0.01, P<0.01$, Table II). Serum CK-MB concentration increased at $120,180 \mathrm{~min}$ after reperfusion compared with the value before surgery $(P<0.01$, Table II). There were no differences between the groups in GEL, CK and CK-MB concentration (Table II). On en- 


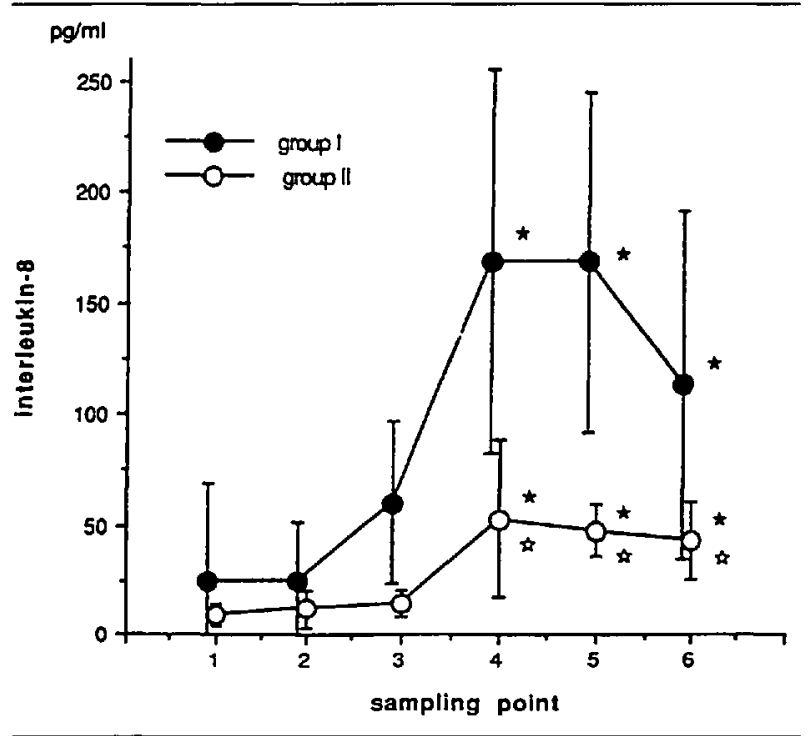

FIGURE 1 IL-8 concentrations at the different times in patients treated with (Group II) or without (Group 1) methylprednisolone. Sampling point (1) before operation (2) pre-CPB (3) $60 \mathrm{~min}$ after aortic clamp (4) $60 \mathrm{~min}$ after declamping of the aorta (5) $120 \mathrm{~min}$ after declamping of the aorta (6) 180 min after declamping of the aorta. Mean \pm SD. $\star P<0.01$ vs before operation. $P<0.05$ vs Group I (without MP)

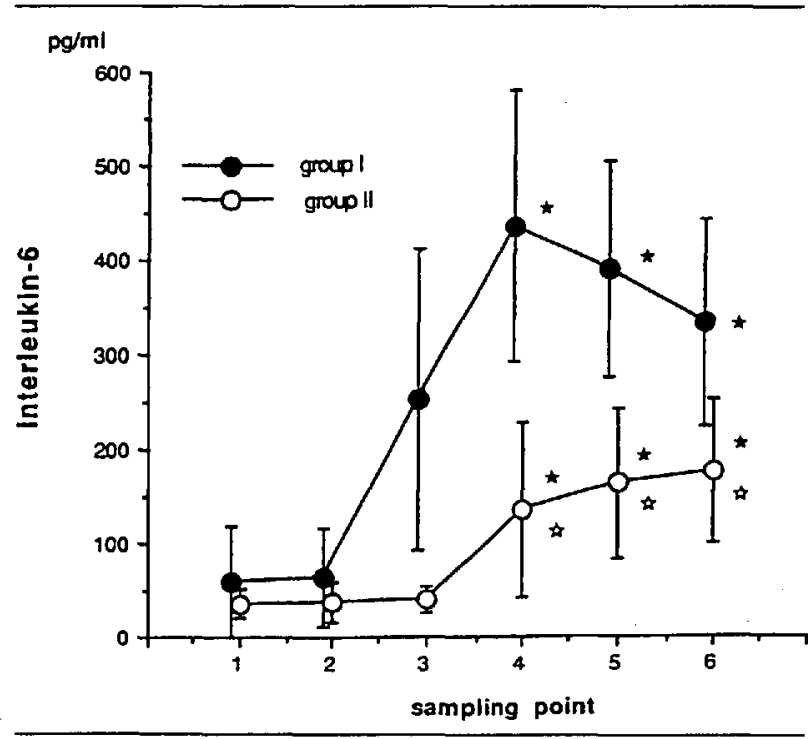

FIGURE 2 IL- 6 concentrations in serum at the different times in patients treated with (Group II) or without (Group I) methylprednisolone. Mean $\pm \mathrm{SD} \star \star P<0.01$ vs before operation. $P<0.05$ vs Group I (without MP)

tering the Intensive Care Unit (ICU) after surgery, the cardiac index was higher in Group II (3.6 \pm 1.1 $\left.\mathrm{L} \cdot \mathrm{min}^{-1} \cdot \mathrm{m}^{-2}\right)$ than in Group I $(2.3 \pm 0.8$ $\left.\mathrm{L} \cdot \min ^{-1} \cdot \mathrm{m}^{-2}\right)(P<0.05)$ and the pulmonary capillary wedge pressure (PCWP) was lower in Group II (9.7 \pm $3.4 \mathrm{mmHg}$ ) than $12.2 \pm 3.9 \mathrm{mmHg}$ in Group I $(P<$ 0.05 ). Cardiac index at the entrance of ICU was correlated negatively with the IL-8 maximum during surgery in Group II ( $\gamma=0.67, P<0.05$, Figure 3).

Doses of catecholamine used after cardiac surgery in ICU were not different between groups. (Group I: dobutamine $7.62 \pm 11.1 \mu \mathrm{g} \cdot \mathrm{kg}^{-1} \cdot \mathrm{min}^{-1}$, dopamine $3.77 \pm 1.6 \mu \mathrm{g} \cdot \mathrm{kg}^{-1} \cdot \mathrm{min}^{-1}$; Group II: dobutamine $10.69 \pm 4.2 \mu \mathrm{g} \cdot \mathrm{kg}^{-1} \cdot \mathrm{min}^{-1}$, dopamine $5.0 \pm 2.0$ $\left.\mu \mathrm{g} \cdot \mathrm{kg}^{-1} \cdot \mathrm{min}^{-1}\right)$.

\section{Discussion}

Free oxygen radicals have been considered to play an important role in post-ischaemic reperfusion injury as a direct cytotoxic factor. However, recent reports showed that monoclonal antibodies of adhesion molecules decrease reperfusion injury and indicate that an interaction between neutrophils and the vascular endothelium may be an important pathogenic factor in post-ischaemic reperfusion injury. ${ }^{11-13}$ Adhesion molecules are expressed on the membrane surface of neutrophils and endothelial cells, and this is followed by their adhesion and activation, which produce various cytotoxic effects. Further, inflammatory cytokines (IL-2, TNF- $\alpha$, IL- 6 , IL-8, etc.), which are produced from monocyte, macrophages or endothelial cells, play an important role in the interaction between neutrophils and vascular endothelium. ${ }^{14,15}$ These cytokines stimulate neutrophils and endothelial cells to express various adhesion molecules on their membrane surface and, accordingly, activate them directly or indirectly.

In our previous study, IL-8, IL- 6 and TNF- $\alpha$ were determined in patients undergoing open heart surgery with cardiopulmonary bypass. The results showed that changes in TNF- $\alpha$, were minimal throughout the perioperative period, but that concentrations of IL- 8 and IL6 increased at 60,120 and 180 min after reperfusion compared with levels before surgery and $60 \mathrm{~min}$ after aortic occlusion. In addition, the changes correlated with the CK-MB and duration of aortic occlusion. These results suggested that the production of IL-8 and IL-6 in the endothelium due to ischaemia was involved in reperfusion injury. ${ }^{4}$ In the present study, methylprednisolone was given to similar patients, on the assumption that its inhibitory effect on the increased production of IL-6 and IL-8 might prevent or suppress reperfusion injury and other post-surgical complications, including low output syndrome (LOS). Methylprednisolone is known to inhibit the release of free oxygen radicals, ${ }^{16}$ in addition to its anti-shock and membrane-stabilizing effect. ${ }^{17}$ It has also been reported recently that methylprednisolone inhibits IL-1, IL-2, IL-6 and TNF- $\alpha$. Imamura et al. have shown in vitro a dose-related reduction in the ability of periph- 
TABLE II Concentrations of plasma granulocyte elastase (GEL), serum creatine phosphokinase (CK), CK-MB in each period

\begin{tabular}{|c|c|c|c|c|c|c|c|}
\hline & \multirow[b]{2}{*}{ Group } & \multicolumn{6}{|c|}{ Sampling points } \\
\hline & & 1 & 2 & 3 & 4 & 5 & 6 \\
\hline $\operatorname{GEL}\left(\mu \mathrm{g} \cdot \mathrm{L}^{-1}\right)$ & $\begin{array}{l}\text { Group I } \\
\text { Group II }\end{array}$ & $\begin{array}{l}164 \pm 47 \\
168 \pm 71\end{array}$ & $\begin{array}{l}158 \pm 36 \\
206 \pm 98\end{array}$ & $\begin{array}{l}422 \pm 325 \\
413 \pm 353\end{array}$ & $\begin{array}{r}927 \pm 446^{*} \\
1059 \pm 517^{*}\end{array}$ & $\begin{array}{l}1195 \pm 648^{*} \\
1134 \pm 453^{*}\end{array}$ & $\begin{array}{l}1189 \pm 198^{*} \\
1062 \pm 467^{*}\end{array}$ \\
\hline $\mathrm{CK}\left(\mathrm{IU} \cdot \mathrm{L}^{-1}\right)$ & $\begin{array}{l}\text { Group I } \\
\text { Group II }\end{array}$ & $\begin{array}{r}161.6 \pm 116 \\
167 \pm 100\end{array}$ & $\begin{array}{r}229.3 \pm 124 \\
198 \pm 119\end{array}$ & $\begin{array}{r}246.9 \pm 73 \\
210 \pm 73\end{array}$ & $\begin{array}{r}428.6 \pm 130^{*} \\
502 \pm 187^{*}\end{array}$ & $\begin{array}{l}519 \pm 240^{*} \\
609 \pm 287^{*}\end{array}$ & $\begin{array}{l}592 \pm 179^{*} \\
621 \pm 274^{*}\end{array}$ \\
\hline CK-MB $\left(I U \cdot L^{-1}\right)$ & $\begin{array}{l}\text { Group I } \\
\text { Group II }\end{array}$ & $\begin{array}{l}0.6 \pm 0.7 \\
0.8 \pm 1.3\end{array}$ & $\begin{array}{l}0.7 \pm 0.9 \\
0.8 \pm 1.8\end{array}$ & $\begin{array}{r}0.71 \pm 1.1 \\
0.4 \pm 1.0\end{array}$ & $\begin{array}{l}4.1 \pm 3.2 \\
6.6 \pm 8.9\end{array}$ & $\begin{array}{c}6.8 \pm 3.2^{*} \\
11.7 \pm 12.2^{*}\end{array}$ & $\begin{array}{l}10.8 \pm 6.8^{*} \\
16.3 \pm 12.5\end{array}$ \\
\hline
\end{tabular}

Sampling times (1) before operation (2) pre-CPB (3) $60 \mathrm{~min}$ after aortic clamp (4) $60 \mathrm{~min}$ after declamping of the aorta (5) $120 \mathrm{~min}$ after declamping of the aorta (6) $180 \mathrm{~min}$ after declamping of the aorta. Mean \pm SD. ${ }^{*} P<0.01$ vs before operation (1).

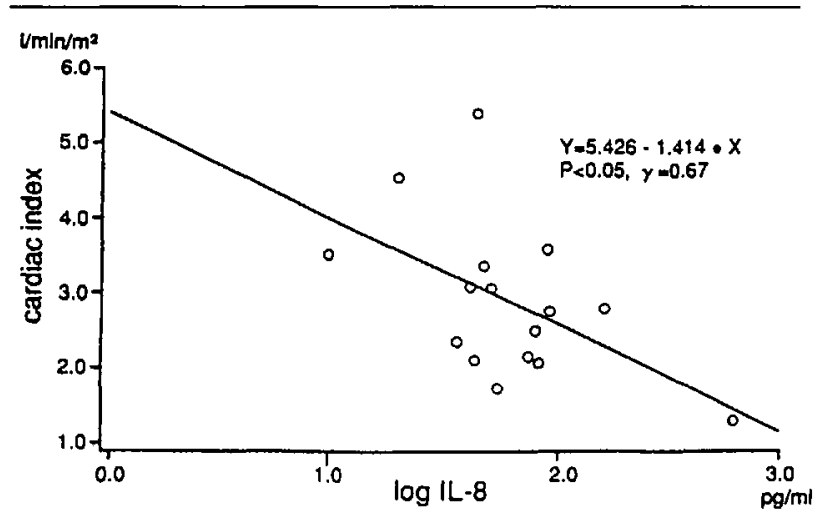

FIGURE 3 Correlation between cardiac index and the maximum level of interleukin 8 during surgery.

eral monocytes macrophages from patients with multiple sclerosis receiving methylprednisolone to produce cytokines (TNF- $\alpha$, IL-1, IL-2, IL- 6 ). ${ }^{18}$ However, there is no evidence that it inhibits the production of IL-6 or IL8 in vivo. We found that MP was effective in suppressing the increased production of cytokines since the concentrations of IL-8 and IL-6 in MP-treated patients were less than those in non-MP-treated patients at each time point after reperfusion. It has been reported that IL-6 levels increase considerably in patients with acute myocardial infarction. ${ }^{19}$ Youker et al. ${ }^{20}$ suggested that the expression of ICAM-1 (intercellular adhesion molecule1) on cardiac myocytes was induced by IL-6 and adhesion of myocytes to leukocytes was potentiated by IL-6, and in this respect was involved in reperfusion injury. Moreover, Finkel et al. ${ }^{21}$ found that IL-6 inhibited myocardial contractility through production of nitric oxide (NO), and suggested that the production of IL-6 might be a pathogenic factor in the stunned myocardium. Whereas, IL8 has been shown to be chemotactic to neutrophils in vitro, and to show various other biological activities including neutrophil activation. Activated neutrophils have been known to induce the release of lysosomal enzymes ${ }^{22,23}$ and the production of leukotriene $\mathrm{B}_{4}{ }^{24}$ and 25 HETE. They have also been shown to potentiate the expression of CR-1, Mac-1 and other factors associated with cell adhesion, and thus to increase the adhesion of neutrophils to unstimulated vascular endothelial cell. . $^{14,15}$ It was found recently that IL-8 was produced in tissure hypoxaemia related to ischaemia in vitro, ${ }^{25}$ suggesting a possible role of IL-8 in post-ischaemic reperfusion injury, myocardial infarction and multiple organ failure (MOF). This evidence strongly suggests that IL-6 and IL-8 are involved in organ damage and the demonstration that two doses of methylprednisolone at $30 \mathrm{mg} \cdot \mathrm{kg}^{-1}$ inhibit the rise in cytokines during open heart surgery may be of clinical importance.

During surgery, serum CK concentration increased at $60,120,180 \mathrm{~min}$ after reperfusion in both groups. The CK-MB also increased in both groups at $120,180 \mathrm{~min}$ after reperfusion. It is known that peak concentrations of CK-MB appear 4 to $12 \mathrm{hr}$ after cell injury, and intraoperative changes remained within the normal range in the present study, suggesting that it is difficult to discuss the protective effect of methylprednisolone on the myocardium, if the discussion is only based on its intraoperative levels. Consequently, we evaluated post-surgical cardiac function. As a result, in MP-treated patients, postsurgical cardiac index was higher and PCWP was lower than those in non-MP-treated patients, nevertheless doses of total cathecholamine used after cardiac surgery in ICU were not different between groups. Furthermore, cardiac index correlated negatively with maximum concentration of IL-8 during surgery, suggesting that MP pretreatment may improve post-surgical cardiac function by suppressing increased production of IL-8.

In summary, the increased production of IL-6 and IL8 during open heart sugery with cardiopulmonary bypass was lower in MP-treated patients than in one-MP-treated patients. 


\section{Acknowledgment}

Appreciation is extended to Dr. Shigeatsu Endo of the Higher Emergency Care Center, Iwate Medical University, for his guidance and advice in writing this paper.

\section{References}

1 Romson JL, Hook BG, Kunkel SL, Abrams GD, Schork $M A$, Lucchesi $B R$. Reduction of the extent of ischemic myocardial injury by neutrophil depletion in the dog. Circulation 1983; 67: 1016-23.

2 Mullane KM, Read N, Salmon JA, Moncada S. Role of leukocytes in acute myocardial infarction in anesthetized dogs: relationship to myocardial salvage by antiinflammatory drugs. J Pharmacol Exp Ther 1984; 228: 510-22.

3 Mullane KM, Moncada S. The salvage of ischaemic myocardium by BW $755 \mathrm{C}$ in anaesthetized dogs. Prostaglandins 1982; 24: 255-66.

4 Kawamura $T$, Wakusawa $R$, Okada K, Inada $S$. Elevation of cytokines during open heart surgery with cardiopulmonary bypass: participation of interleukin 8 and 6 in reperfusion injury. Can J Anaesth 1993; 40: 1016-21.

5 Peces R, Urra JM, Gorostidi M, López-Larrea C. Role of maintenance immunosuppression and methylprednisolone in OKT3-induced cytokine release. Transplant Proc 1992; 24: 2596-9.

6 Alegre $M-L$, Vandenabeele P, Depierreux $M$, et al. Cytokine release syndrome induced by the $145-2 \mathrm{Cll}$ antiCD3 monoclonal antibody in mice: prevention by high doses of methylprednisolone. J Immunol 1991; 146: 1184-91.

7 Lane NE, Williams RJ III, Schurman DJ, Smith RL. Inhibition of interleukin 1 induced chondrocyte protease activity by a corticosteroid and a nonsteroidal antiinflammatory drug. J Rheumatol 1992; 19: 135-9.

8 Lew W, Oppenheim JJ, Matsushima K. Analysis of the suppression of IL- $1 \alpha$ and IL-1 $\beta$ production in human peripheral blood mononuclear adherent cells by a glucocorticoid hormone. J Immunol 1988; 140: 1895-902.

9 Ida N, Sakurai S, Hosoi K, Kunitomo T. A highly sensitive enzyme-linked immunosorbent assay for the measurement of interleukin-8 in biological fluids. J Immunol Methods 1992; 156: 27-38.

10 Ida N, Sakurai S, Hosaka T, et al. An enzyme-linked immunosorbent assay for the measurement of human interleukin-6. J Immunol Methods 1990; 133: 279-84.

11 Simpson PJ, Todd RF III, Fantone JC, et al. Reduction of experimental canine myocardial reperfusion injury by a monoclonal antibody (anti-Mol, anti-CD 11b) that inhibits leukocyte adhesion. J Clin Invest 1988; 81: 624-9.

12 Simpson PJ, Todd RF III, Michelson JK, et al. Sustained limitation of myocardial reperfusion injury by a monoclo- nal antibody that alters leukocyte function. Circulation 1990; 81: 226-37.

13 Vedder NB, Winn RK, Rice $C L$, Chi EY, Arfors $K-E$, Harlan JM. A monoclonal antibody to the adherencepromoting leukocyte glycoprotein, CD18, reduces organ injury and improves survival from hemorrhagic shock and resuscitation in rabbits. J Clin Invest 1988; 81: 939-44.

14 Paccaud J-P, Shifferli JA, Baggiolini M. NAP-1/IL-8 induces up-regulation of CRl receptors in human neutrophil leukocytes. Biochem Biophys Res Comm 1990; 166: 187-92.

15 Detmers PA, Lo SK, Olsen-Egbert E, Walz A, Baggiolini $M$, Cohn $Z A$. Neutrophil activating protein $1 /$ interleukine 8 stimulates the binding activity of the leukocyte adhesion receptor CD11b/CD18 on human neutrophils. J Exp Med 1990; 171: 1155-62.

16 Yoshikawa T, Ichikawa H, Takano H, et al. Effects of methylprednisolone on superoxide production from human polymorphonuclear leukocytes stimulated by various stimulants. Japanese Journal of Clinical and Experimental Medicine 1991; 156: 139-40.

17 Lefer $A M$, Verrier RL. Role of corticosteroids in the treatment of circulatory collapse states. Clin Pharmacol Ther 1970; 11: 630-55.

18 Imamura K, Hayashi F, Suzumura A. Cytokine production by peripheral blood monocytes/macrophages in the patients with multiple sclerosis and its suppression by methylprednisolone. Jpn Clin Neurol 1992; 32: 276-80.

19 Ikeda U, Ohkawa F, Seino Y, et al. Serum interleukin 6 levels become elevated in acute myocandial infarction. $J$ Mol Cell Cardiol 1992; 24: 579-84.

20 Youker $K$, Smith $C W$, Anderson DC, et al. Neutrophil adherence to isolated adult cardiac myocytes. Induction by cardiac lymph collected during ischemia and reperfusion. $\mathrm{J}$ Clin Invest 1992; 89: 602-9.

21 Finkel MS, Oddis CV, Jacob TD, Watkines SC, Hatller $B G$, Simmons $R L$. Negative intropic effects of cytokines on the heart mediated by nitric oxide. Science 1992; 257 : 387-9.

22 Schröder J-M, Mrowietz U, Morita E, Christophers E. Purification and partial biochemical characterization of a human monocyte-derived neutrophil activating peptide that lacks interleukin 1 activity. J Immunol 1987; 139: 3474-83.

23 Peveri P, Walz A, Dewald B, Baggiolini $M$. A novel neutrophil-activating factor produced by human mononuclear phagocytes. J Exp Med 1988; 167: 1547-59.

24 Schroder J-M. The monocyte-derived neutrophil activating peptide (NAP/interleukin 8) stimulates human neutrophil archidonate-5-lipoxygenase, but not the release of cellular arachidonate. J Exp Med 1989; 170: 847-63.

25 Metinko A, Kunkel S, Standiford T, Strieter R. Monocyte expression of interleukin- 8 in response to oxidant stress (Abstract). FASEB J 1991; A704-1941. 